Yüzüncü Y1l Üniversitesi
Tarim Bilimleri Dergisi

Araştırma Makalesi (Research Article)

\title{
Mardin İlindeki Küçükbaş Hayvancılık İşletmelerinin Yapısal Durumu**
}

\author{
Veysi ACIBUCA ${ }^{1 *}$, Dilek BOSTAN BUDAK ${ }^{2}$ \\ ${ }^{1}$ Mardin Artuklu Üniversitesi, Kızıltepe Meslek Yüksekokulu, Bitkisel ve Hayvansal Üretim Bölümü,47000 \\ Mardin, Türkiye \\ ${ }^{2}$ Çukurova Üniversitesi, Ziraat Fakültesi, Tarım Ekonomisi Bölümü,01330 Adana, Türkiye \\ ${ }^{1}$ https://orcid.org/0000-0002-8478-7300 2https://orcid.org/0000-0001-6318-698X
}

*Sorumlu yazar e-posta: veysiacibuca@artuklu.edu.tr

\section{Makale Bilgileri}

Geliş: 21.04.2021

Kabul: 21.11.2021

Online Yayınlanma: 15.12.2021

DOI: $10.29133 /$ yyutbd.925141

\section{Anahtar Kelimeler}

Küçükbaş hayvancılık, Mardin,

Sosyo-ekonomik durum.
Öz: Bu çalışma, Mardin ilinde küçükbaş hayvancılık üreticilerinin sosyoekonomik özellikleri, desteklemelerden faydalanma durumları, birliğe üye olma durumları, hayvan sağlığı uygulamaları ve sorunlarını tespit etmek amacıyla yapılmıştır. Çalışma 2019 yılı Şubat ve Haziran ayları arasında yürütülmüş olup araştırma materyalini Mardin ilinin 4 ilçesinde tabakalı tesadüfi örnekleme yöntemiyle seçilen 142 işletmede yapılan anket verileri oluşturmaktadır. Çalışmadan elde edilen veriler neticesinde işletmelerde ortalama 197.4 baş hayvan varlığı olduğu ve işletmelerin \% 16.2'sinin hayvancılığ sadece ailenin hayvansal ürün ihtiyacını karşıllamak amacıyla yaptığı tespit edilmiştir. İşletmelerde hayvan sayısı arttıkça bilgiye ulaşma isteği ve desteklemelerden faydalanma durumunda artış gözlenmiştir. Elde edilen sonuçlar neticesinde Mardin ilinde küçükbaş hayvancılık faaliyetlerinin gelişmesini önleyen en önemli faktörlerin başında yem giderlerinin yüksek olması ve çoban sıkıntısının geldiği belirlenmiş olup gençlerin hayvancılık faaliyetlerine yönlendirilmesi için çobanlık mesleğinin cazibeli hale getirilmesi önerilmiştir.

\section{Structural Situation of Small Ruminant Enterprises in Mardin Province}

\section{Article Info}

Received: 21.04 .2021

Accepted: 21.11.2021

Online Published: 15.12 .2021

DOI: $10.29133 /$ yyutbd.925141

\section{Keywords}

Ovine livestock,

Mardin,

Socio-economic situation.

\begin{abstract}
The current study was undertaken to investigate the socio-economic characteristics, the situations of benefits from subsidies, the participation of union membership, and the animal care practices and problems of the small ruminants' farmers in Mardin. The study was conducted between February and June 2019 by analyzing self-reported questionnaire data involving 142 participant enterprises selected by stratified random sampling method in 4 districts of Mardin province. Analyzed data obtained from the study displayed that there was an average of 197.4 heads of animals in the enterprises, and $16.2 \%$ of the enterprises were engaged in livestock production only to meet their family needs. As the number of animals increased in the enterprises, the desire to reach the information and the situation of benefiting from the supports increased. Results obtained showed that the most important factors preventing the development of small ruminant farming activities in Mardin province were high feed costs and shepherd shortage. In line with this data, making the shepherding occupation attractive was suggested to tend young people to be employed in the small livestock-keeping activities.
\end{abstract}

\footnotetext{
${ }^{* *}$ Bu çalışma Veysi ACIBUDA’nın doktora tezinden üretilmiştir.
} 


\section{Giriş}

Hayvancılık faaliyetlerinin alt sektörlerinden birisi olan küçükbaş hayvancılık; et, süt ve süt ürünleri ile deri, kıl ve yün üretimi gibi dünya ekonomisinde önemli bir yeri olan insanoğlunun en kadim ekonomik faaliyetlerinden birisidir. Koyun ve keçiler; düşük bakım gereksinimleri, beslenmede marjinal arazileri değerlendirebilmeleri ve yatırım maliyetlerinin düşük olması gibi avantajları nedeniyle hem kırsal kesimdeki yoksul insanların refah seviyelerinin yükseltilmesi hem de hayvansal ürün talebinin karşılanmasında önemli rol oynamaktadırlar. Gıda güvenliği, insan sağlığı ve ekonomik faydalarının yanında, küçükbaş hayvancıllk özellikle Afrika ülkelerinde sosyal statünün belirlenmesinde de önemli bir faaliyet olarak görülmektedir (Thornton, 2010).

Gıda ve Tarım Örgütü (FAO) verilerine göre 2019 yılında dünya genelindeki toplam koyun sayısı 1.238 milyon baş, keçi varlığı ise yaklaşık 1.094 milyon baştır (FAO, 2019). Aynı verilere göre Çin 163.5 milyon baş koyun varlığılla birinci sırada yer alırken, Hindistan ise 148.9 milyon baş ile keçi varlığında ilk sırada yer almaktadır. Küçükbaş hayvan varlığının kıtalara dağılımında da Asya kıtası hem koyun hem keçi varlığı bakımından birinci sırada yer almaktadır. 2019 yılı Dünya toplam koyun varlığının \% 42.6's1 (527.2 milyon baş), keçi varlığının ise \% 52.6's1 (575.5 milyon baş) Asya kıtasında yer almaktadır (FAO, 2019). Dünya genelinde artan nüfus, kentleşme ve gelir artışı ile birlikte hayvansal ürünlere talep artmaktadır (Delgado et al., 2001). 2050 yılında hayvansal ürünlere olan talebin yaklaşık \% 70.0 oranında artarak bütçenin 9.6 milyar Euro'ya ulaşması beklenmektedir (FAO, 2014).

Küçükbaş hayvancılık Türkiye'nin tüm bölgelerinde sürdürülen önemli bir faaliyet olup genellikle düşük verimli yerli ırklardan oluşan ve ağırlıklı olarak otlatmaya dayalı besleme koşulları ve sınırlı girdi ile üretimin hedeflendiği ekstansif bir yapıya sahiptir (Semerci ve Çelik, 2016). Türkiye İstatistik Kurumu (TÜIK) 2020 yılı verilerine göre Türkiye'nin küçükbaş hayvan varlığ 1 toplamı 54.1 milyon baş olup koyun varlığı 42.12 milyon baş, keçi varlığı ise 11.98 milyon baştır (TÜiK, 2020). Doğu Anadolu Bölgesi toplam küçükbaş hayvan varlığının \% 23.9'una (12.9 milyon baş) sahip olup birinci sırada, Güneydoğu Anadolu Bölgesi ise 10.5 milyon baş (\%19.5) ile ikinci sırada yer almaktadır. Koyun varlığı bakımından Güneydoğu Anadolu Bölgesi birinci sırada yer alırken, keçi varlığı bakımından ise Akdeniz Bölgesi birinci sırada yer almaktadır. Karadeniz Bölgesi hem koyun hem de keçi sayısı bakımından en düşük küçükbaş hayvan varlığına sahip bölgedir (TÜİK, 2020).

Son yıllarda tarımsal üretim değerlerindeki azalma tarımsal üretim artışını ve sektörün daraldığını göstermekle birlikte (Karaman, 2018) meydana gelen yüksek girdi maliyetleri hayvancıllı̆ın sürdürülebilirliğine önemli derecede etki etmiş (Güler ve Saner, 2021) ve buna bağlı olarak canlı hayvan ve karkas ithalatını artmıştır. Ülkemizdeki büyükbaş ve küçükbaş hayvan varlığı toplamı 2000 ile 2010 yılları arasında genel olarak 37-45 milyon baş arasında olup belirtilen dönemde 2005 ve 2006 yılları dışındaki tüm yıllarda hayvan varlığında bir önceki yıla göre azalma olmuştur. 2010 yılından sonra özellikle et fiyatlarının düşürülmesi amacıyla çoğunluğu besilik ve kasaplık olmak üzere canlı hayvan ithalatı hızlanmış ve 2010-2019 yılları arasında toplam 7.08 milyar dolar değerinde yaklaşık 8 milyon baş canlı küçükbaş/büyükbaş hayvan ithalatı yapılmıştır (ESK, 2019). 2010-2019 yılları arasında toplam 1.406 milyar dolar değerinde 296487 ton kemikli/kemiksiz/karkas et ithalatı yapılmıştır (ESK, 2019).

Türkiye'de son on beş yılda hayvancılık sektörüne verilen hibe, kredi ve desteklemeler ile çoğunlukla büyük ölçekli işletmelerin faydalandığı bir yapı oluşturulmaya çalışılmış, böylece et ve süt verimliliğinin arttırılarak ülkenin ihtiyacı olan hayvansal ürünlerin yurt içinden temin edilmesi, dolayısıyla ürün fiyatlarının yükselmesinin önlenmesi amaçlanmıştır. Hayvancılık ile ilgili desteklemeler özellikle 2005 y1lından sonra çeşitlenmiş, yem bitkileri, süt teşvik primi, suni tohumlama ve buzağı destekleri en önemli destekleme araçları olmuştur (Ata ve Yılmaz, 2015).

Bu çalışma 2020 yılı verilerine göre Türkiye'nin toplam koyun varlığının \% 1.5 (626 219 baş)'i ile keçi varlığının \% 3.9 (462 139 baş)'una sahip olan Mardin ilinin küçükbaş hayvan varlığı potansiyeli, işletmelerin sosyo-ekonomik durumları ile desteklemelerden faydalanma durumları, hayvan sağlığı uygulamaları ve sorunlarının tespit edilmesi amacıyla yapılmıştır. Çalışmadan elde edilen sonuçların Mardin ilinde küçükbaş hayvancılık faaliyetlerinin geliştirilmesi ve ilgili kurumların yapabileceği proje, yayım faaliyetleri ile stratejik planlamalara katkı sağlaması hedeflenmektedir. 


\section{Materyal ve Yöntem}

Çalışmanın ana materyalini Mardin ilinde küçükbaş hayvancılık faaliyeti yapan tarım işletmelerinden 2019 yılı Şubat ve Haziran ayları arasında anket yoluyla elde edilen veriler oluşturmaktadır. Ayrıca konuyla ilgili önceden yapılmış çalışmalar, kamu ve özel kuruluşlardan sağlanan bilgiler ve uzman görüşleri de çalışmada kullanılan ikincil veriler kullanılmıştır. Mardin ilinde toplam on ilçe bulunmakta olup zaman, maliyet ve bazı ilçelerin terör olaylarından dolayı güvenli olmaması nedeniyle tüm ilçelerde anket yapılmamıştır. Bu nedenle birinci aşamada koyun ve keçi yetiştiriciliğinin yoğun olarak yapıldığı dört ilçe (Artuklu, Derik, Mazıdağı ve Savur) gayeli olarak seçilmiştir. Bu 4 ilçedeki üretici sayıları popülasyondaki işletme sayısını oluşturmuştur.

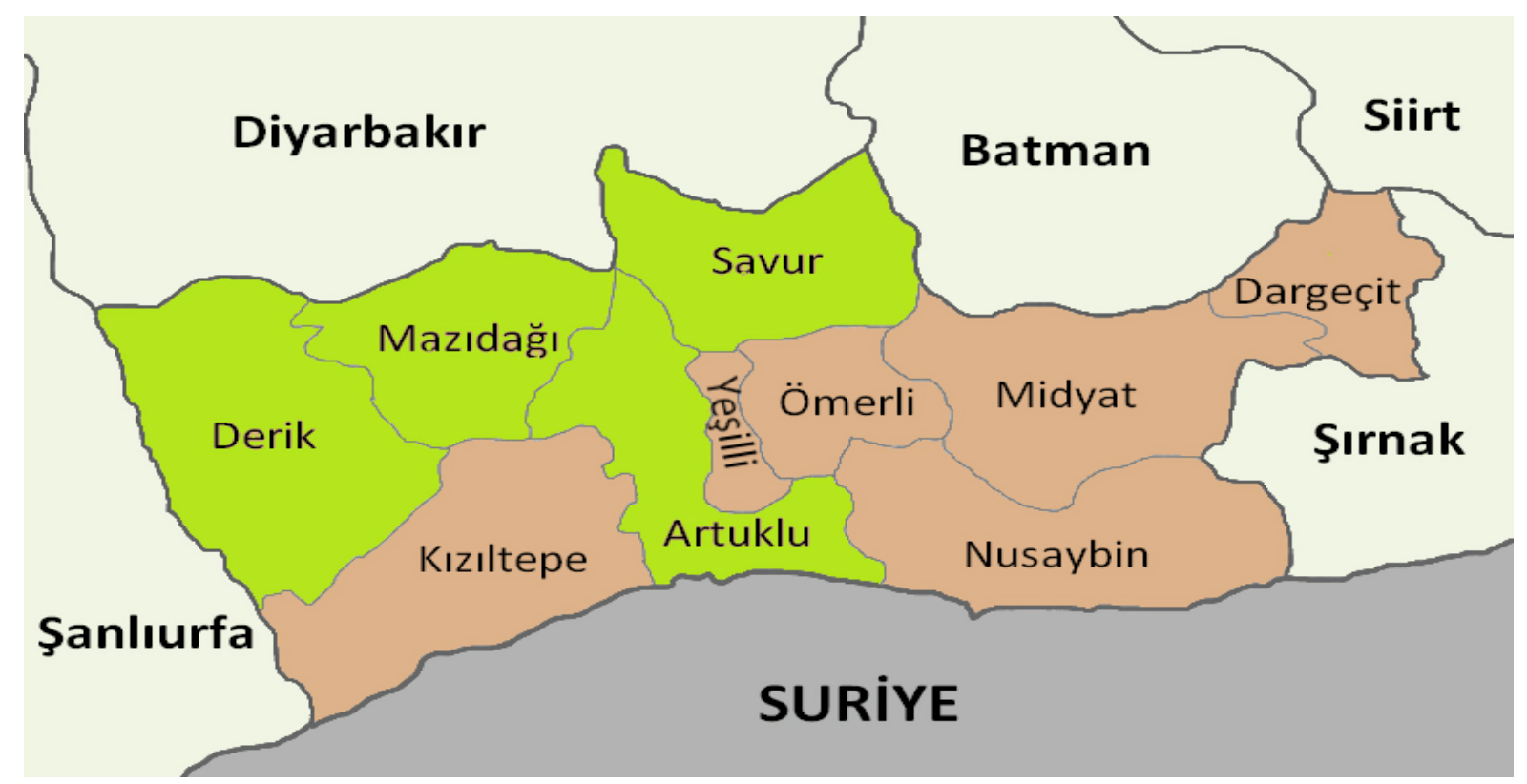

Şekil 1. Mardin ilinde çalışmanın yapıldığı ilçeler (Anonim, 2021).

Araştırma neticesinde elde edilecek bilgilerin doğruluğunu arttırmak ve ana kitledeki farklı büyüklükteki işletmelerin yeterli düzeyde temsil edilebilmesini sağlamak amaciyla tabakalı tesadüfi örnekleme yöntemi kullanılmıştır. Tabakalı tesadüfi örnekleme yöntemine göre belirlenen örnek hacmi aşağıdaki yöntemle belirlenmiştir (Esin ve ark. 2001).

$$
\begin{gathered}
\mathrm{n}=\frac{\left(\sum \mathrm{N}_{\mathrm{h}} \cdot \mathrm{S}_{\mathrm{h}}\right)^{2}}{\mathrm{~N}^{2} \cdot \mathrm{D}^{2}+\sum \mathrm{N}_{\mathrm{h}} \cdot \sum \mathrm{S}_{\mathrm{h}}} \\
\mathrm{D}^{2}=\frac{\mathrm{d}^{2}}{\mathrm{z}^{2}}
\end{gathered}
$$

n: Örnek hacmini

$\mathrm{N}_{\mathrm{h}}$ : h'ıncı tabakadaki işletme sayısını $\mathrm{h}$

$\mathrm{S}_{\mathrm{h}}$ : h'inc1 tabakanın standart sapmasinı

$\mathrm{S}_{\mathrm{h}}{ }^{2}$ : h'inci tabakanın varyansinı

$\mathrm{N}$ : Populasyondaki işletme sayısını

d: Populasyon ortalamasindan izin verilen hata pay1,

z: Hata oranına göre standart normal dağılım tablosundaki z değerini ifade etmektedir.

Örnek hacmi \% 95 güven aralığ 1 ve \% 5 hata payı ile 129 olarak hesaplanmıştır. Veri analizinde herhangi bir sorunla karşılaşmamak için örnek büyüklügünün \% 10 fazlası kadar anket yapılarak toplamda 142 anket yapılmıştır. İşletmelerin tabakalara ayrılmasında Damızlık Koyun Keçi Yetiştiricileri Birliği (DKKYB)'nden alınan ortalama hayvan varlığı esas alınmıştır. Buna göre 130 baş 
altındaki hayvan varlığına sahip işletmeler I. tabaka, $130-260$ baş arası II. tabaka ve 260 baş üzeri hayvan varlığına sahip işletmeler III. tabakada yer almıştır. Birinci tabakada 43, ikinci tabakada 47 ve üçüncü tabakadaki işletmelerde 52 işletme hesaplanmıştır.

Çizelge 1. Tabakalara göre ilçelerde yapılan anket sayıları (adet)

\begin{tabular}{|c|c|c|c|c|c|}
\hline \multirow{2}{*}{ Tabakalar } & \multicolumn{4}{|c|}{ İlçeler } & \multirow{2}{*}{ Toplam } \\
\hline & Artuklu & Savur & Derik & Mazıdağı & \\
\hline$<130$ Baş & 11 & 18 & 9 & 5 & 43 \\
\hline $130-260$ Baş & 4 & 12 & 19 & 12 & 47 \\
\hline >260 Baş & 9 & 10 & 16 & 17 & 52 \\
\hline Toplam & 24 & 40 & 44 & 34 & 142 \\
\hline
\end{tabular}

Anket çalışması neticesinde elde edilen veriler SPSS paket programına yüklenmiş ve araştırmanın amacına uygun istatistiksel yöntemler kullanılarak analiz edilmiştir. Bu bağlamda üreticiler ve işletmeler ile ilgili tanımlayıcı istatistikler (frekans, yüzde, ortalama vb.) değerlerle ifade edilmiştir. Değişkenler arasındaki ilişkinin incelenmesi için parametrik olmayan testlerden Ki-kare analizi yapılmıştır. Ki-kare testi iki ya da daha çok grup arasında fark olup olmadığı test etmek için kullanılmakta olup temel amaç gözlenen ve beklenen frekanslar arasındaki farkın anlamlı olup olmadığının tespit edilmesidir.

\section{Bulgular}

\section{1. Üreticilerin sosyo-demografik özellikleri}

Araştırma neticesinde üreticilerin \% 97.8'inin erkek, \% 2.2'sinin ise kadın olduğu, yaşlarının 19 ile 73 arasında değişmekte birlikte yaş ortalamaların 44.1 olduğu tespit edilmiştir. Otuz yaş ve altındaki üreticiler ise toplam üreticilerin \% 15.5'ini oluşturmaktadır. Üreticilerin \% 85.9'u evli bireylerden oluşmakta olup ortalama hane halkı genişliği 6.6 kişi olarak saptanmıtır. Türkiye'de yapılan tarım faaliyetlerinde üreticilerin yaş ortalamalarının yüksek olduğu ve kırsal kesimlerde hane halkı ortalamasının ülke ortalamasından yüksek olduğu yapılan birçok araştırmada ortaya konulmuştur. Bakır ve Mikail (2019)'in Siirt ilinde küçükbaş hayvan yetiştiriciliği ile ilgili yaptıkları çalışmada işletmecilerin yaş ortalamasının 47.0 yıl, Şanlıurfa ilinde koyunculuk işletmelerinin yapısal analizinin yapıldığ 1 çalışmada ise ortalama hane halkı büyüklüğü 7.9 kişi olarak bulunmuştur (Karadaş, 2018).

Üreticilerin \% 12.0'^ hiç eğitim almamış olup \% 37.3'ü ilkokul, \% 18.3'ü ortaokul, \% 27.5'i lise ve \% 4.9'u önlisans eğitimi almış bireylerden oluşmaktadır. Karakaya ve Kızıloğlu (2014)'nun Bingöl ilinde yaptıkları çalışmada üreticilerin \% 81.6'sının ortaokul ve altı eğitim seviyesine sahip olduğu belirtilmiştir. İncelenen üreticilerin \% 43.0'ının sosyal güvencesinin, \% 40.8'inin tarım dışı gelire sahip olduğu belirlenmiştir. Tarım dışı gelire sahip olanların \% 38.6'sı kendine ait işyeri olduğunu, \% 36.8'i kamuda çalıştığını (genellikle güvenlik korucusu), \% 7.0'1 emekli olduğunu, \% 7.0'1 özel sektörde çalıştığını ve \% 10.6'sı diğer (yaşlılık, engelli maaşı..vs) gelirleri olduğu tespit edilmiştir. İncelenen işletme büyüklüklerine göre üreticilerin sosyal güvenceye ve tarım dışı gelire sahip olması açısından anlamlı bir farklılık olmadığı $(\mathrm{p}>0.05)$ tespit edilmiştir.

\section{2. İşletmelerin genel özellikleri}

İncelenen işletmelerde üreticilerin \% 72.5'inin küçükbaş hayvancılık faaliyetini en az 10 yıldır sürdürdüğü belirlenmiştir. Hayvancılık deneyimi açısından incelenen işletme büyüklükleri arasında anlamlı bir farklılık bulunmamaktadır. Üreticilerin \% 47.9'u ticari amaçla, \% 28.9'u başka geliri olmadığ için, \% 16.2'si ailenin hayvansal ürün ihtiyacını karşılamak amacıyla ve \% 7.0'1 alışkanlıktan dolayı küçükbaş hayvancılık faaliyeti yaptığını belirtmiştir. Üreticilerin \% 89.4'ünün DKKYB'ye üye olduğu bu oranının 130 baş hayvan sayısı altındaki işletmelerde $\% 69.8$ olduğu belirlenmiştir. İncelenen işletme büyüklükleri arasında hayvancılığı yapma amacı bakımından 0.05 , DKKYB üyeliği bakımından ise 0.01 düzeyinde anlamlı farklılık olduğu tespit edilmiştir. İşletmelerde hayvan sayısı arttıkça birliğe 
üye olma durumu artmakta ve hayvancılık ekonomik amaçlarla yapılmaktadır. Birliğe üye olan üreticilerin \% 83.1'i desteklemelerden faydalanabilmek amaciyla birliğe üye olduğunu belirtmiştir.

Çizelge 2. İşletmelerde hayvancılık faaliyetini yapma amacı ve DKKYB üyeliği

\begin{tabular}{lccccrrr}
\hline \multirow{2}{*}{$\begin{array}{c}\text { İsletme } \\
\text { Büyüklü̆̈̆ü }\end{array}$} & \multicolumn{3}{c}{ Hayvancilı̆̆ Yapma Amacı (\%)* } & \multicolumn{3}{c}{ DKKYB Üyeliği (\%)** } \\
\cline { 2 - 7 } & Ticari & $\begin{array}{c}\text { Başka geliri } \\
\text { yok }\end{array}$ & $\begin{array}{c}\text { Ailenin } \\
\text { Hayvansal ürün } \\
\text { ihtiyacı için }\end{array}$ & Alışkan & Evet & Hayır \\
\hline$<130$ Baş & 20.9 & 23.3 & 41.8 & 13.9 & 69.8 & 30.2 \\
$130-260$ Baş & 51.1 & 31.9 & 10.6 & 6.4 & 95.7 & 4.3 \\
$>260$ Baş & 67.3 & 30.7 & 0.0 & 1.9 & 100.0 & 0.0 \\
Ortalama & $\mathbf{4 7 . 9}$ & $\mathbf{2 8 . 9}$ & $\mathbf{1 6 . 2}$ & $\mathbf{7 . 0}$ & $\mathbf{8 9 . 4}$ & $\mathbf{1 0 . 6}$ \\
\hline
\end{tabular}

${ }^{*} \mathrm{p}<0.05$ düzeyinde anlamlıdır.

$* * \mathrm{p}<0.01$ düzeyinde anlamlıdır.

İşletmelerde hayvan sayısı 17 ile 690 baş arasında değişmekte olup ortalama hayvan sayısı 197.4 baş olarak tespit edilmiştir. İncelenen işletmelerin \% 13.4'ünde sadece koyunculuk, \% 10.5'inde sadece keçicilik yapılırken \% 76.1'inde hem koyun hem keçi yetiştiriciliği birlikte yapılmaktadır. Ortalama hayvan sayısının en düşük olduğu ilçe Savur (154.7 baş), en yüksek olduğu ilçe ise Mazıdağı (241.3 baş) olarak bulunmuştur. 130 baş altındaki hayvan varlığ 1 en fazla Savur ilçesinde (\% 44.4) bulunurken, 130-260 baş arası hayvan varlığı Derik İlçesinde (\% 41.1) ve 260 baş üzeri hayvan varlığının da Mazıdağ ilçesinde (\% 32.9) bulunduğu tespit edilmiştir. Karacadağ bölgesinde yer alan Derik ve Mazıdağ 1 ilçelerinde hayvancılık faaliyetleri daha büyük sürüler halinde yapılmaktadır. Küçükbaş hayvancılık faaliyetleri ile ilgili yapılan çalışmalarda işletmelerdeki ortalama hayvan sayısını Ceyhan ve ark. (2015) Niğde ilinde 327.6 baş, Bilginturan ve Ayhan (2008) Burdur ilinde 112.8 baş olarak bulmuşlardır. Araştırma bölgesinde genel olarak sıcak ve kurak iklim koşullarına adapte olmuş İvesi koyunu yetiştiriciliği yapılırken, ilin Karacadağ bölgesinde bulunan Mazıdağı ve Derik ilçelerinde ise dağlık/taşlı araziler ile yöreye adapte olmuş Zom koyunu yetiştiriciliği yapılmaktadır. Bölgede kıl keçisi yetiştiriciliğinin yaygın olarak sürdürüldüğü ancak modern ağıl tipine sahip bir işletmede ikizlik oranı yüksek Kilis keçisi yetiştiriciliği yapıldığı ve Savur ilçesindeki bazı işletmelerde tiftik keçisi yetiştiriciliği de yapıldığı tespit edilmiştir.

Çizelge 3. İlçe bazında küçükbaş hayvan işletmelerinin tabakalara göre dağılımı (\%)

\begin{tabular}{lrrrrr}
\hline \multirow{2}{*}{ Tabaka } & \multicolumn{4}{c}{ İlçeler } & \multirow{2}{*}{ Toplam } \\
\cline { 2 - 5 } & Savur & Artuklu & Derik & Mazıdağ & \\
\hline$<130$ Baş & 44.4 & 20.6 & 22.5 & 12.5 & 100.0 \\
$130-260$ Baş & 25.0 & 7.9 & 41.1 & 26.0 & 100.0 \\
$>260$ baş & 17.6 & 18.6 & 30.9 & 32.9 & 100.0 \\
\hline
\end{tabular}

İşletmelerin \% 92.3'ünde hayvanları otlatmak için köy ortak merası kullanılırken, \% 4.2'si kendi arazisinde, \% 2.1'i kiralık merada hayvanlarını otlattı̆̆ını ifade etmiştir. Üreticilerin \% 1.4'ü ise çobanlık yapacak kimseleri olmadığı için hayvanlarını otlatmadığını belirtmiştir. Tarımsal faaliyetlerde iş ve aile yaşantısının bir bütün olması ve kurumsallaşmanın olmaması nedeniyle, işletmelerde işgücü gerektiren faaliyetlerde genellikle çalışabilen aile fertlerinin tamamı uğraşmaktadır. İncelenen işletmelerde küçükbaş hayvancılık faaliyetlerinde tüm aile fertlerinin etkisi olduğu ve birden fazla faaliyette etkilerinin bulunduğu tespit edilmiştir. 7-14 yaş arasındaki kız çocukları en fazla ağıl temizliği (\% 33.1) ve yemleme (\% 16.9) faaliyetlerinde çalışırken, aynı yaştaki erkek çocuklar ise en fazla otlatma (\% 66.9) ve ağıl temizliği (\% 48.6) işlerinde çalışmaktadır. Yapılan faaliyetlerde kadın ve çocukların etkisinin yüksek olduğu işletmeler ortalamasında yapılan faaliyetlerin \% 57.6'sının kadın ve çocuklar tarafından yürütüldüğ̈̈ tespit edilmiştir.

İncelenen işletmelerde küçükbaş hayvancılık desteklemelerinden faydalanma oranları araştırılmış ve üreticilerin \% 98.6'sının hayvanlarının Tarım ve Orman İ/İlçe Müdürlüklerinde kayıtlı 
olduğu ve \% 89.4'ünün destekleme uygulamalarından faydalandığı tespit edilmiştir. Desteklemelerden faydalanamayanların \% 33.3'ü bürokratik işlemlerin fazla olması, \% 26.7'si destek miktarının az olması, \% 20.0'ı nasıl alınacağını bilmediği için, \% 6.7'si desteklerden haberi olmaması nedeniyle ve \% 13.3'ü ise hayvanları kayıtlı olmadığı için destek alamadığını ifade etmiştir. İşletmelerin desteklemelerden faydalanması bakımından işletme büyüklükleri arasında anlamlı $(\mathrm{p}<0.01)$ farklılık bulunmuştur. İşletmelerde hayvan sayısı arttıkça desteklemelerden faydalanma oranı da artmaktadır. Siirt ilinde yapılan çalışmada (Bakır ve Mikail 2019), küçükbaş hayvancılık desteklemelerinden faydalanan işletmelerin oranı \% 86.0 Öğel (2018)'in Şırnak ilinde yaptığı çalışmada ise desteklemelerden faydalanan işletmelerin oranı $\% 76.1$ olarak bulunmuştur.

Çizelge 4. İşletmelerin desteklemelerden faydalanma durumları

\begin{tabular}{|c|c|c|c|c|c|c|c|}
\hline \multirow{2}{*}{\multicolumn{2}{|c|}{ İşletme Büyüklüğü }} & \multicolumn{2}{|c|}{$\begin{array}{c}\text { Desteklemelerden } \\
\text { Faydalanma } \\
\text { Durumu** }\end{array}$} & \multicolumn{4}{|c|}{ Faydalanılan Destekler } \\
\hline & & & & Anac & & & \\
\hline \multirow{2}{*}{$<130$ baş } & $\mathrm{N}$ & 30.0 & 13.0 & 29.0 & 1.0 & 0.0 & 0.0 \\
\hline & $\%$ & 69.8 & 30.2 & 67.5 & 2.3 & 0.0 & 0.0 \\
\hline \multirow{2}{*}{ 130-260 baş } & $\mathrm{N}$ & 45.0 & 2.0 & 40.0 & 3.0 & 2.0 & 0.0 \\
\hline & $\%$ & 95.7 & 4.3 & 85.1 & 6.3 & 4.3 & 0.0 \\
\hline \multirow{2}{*}{ > 260 baş } & $\mathrm{N}$ & 52.0 & 0.0 & 39.0 & 6.0 & 4.0 & 3.0 \\
\hline & $\%$ & 100.0 & 0.0 & 75.0 & 11.5 & 5.8 & 7.7 \\
\hline \multirow{2}{*}{ Ortalama } & $\mathbf{N}$ & 127.0 & 15.0 & 108.0 & 10.0 & 6.0 & 3.0 \\
\hline & $\%$ & 89.4 & 10.6 & 76.1 & 7.0 & 4.2 & 2.1 \\
\hline
\end{tabular}

${ }^{* *} \mathrm{p}<0.01$ düzeyinde anlamlıdır.

Küçükbaş hayvancılık faaliyetinde başarı ve sürdürülebilirliği etkileyen temel faktörlerden birisi de hayvan sağlığı uygulamalarıdır. Hayvan sağlığı uygulamalarının zamanında ve etkin bir şekilde yapılması, hayvanların hem beslenme hem de üreme kapasitesinin artmasına dolayısiyla yapılan faaliyetin kârlılığının artmasına önemli derecede katkı sağlamaktadır. İşletmelerde son bir yıl içerisinde \% 70.4'ünde yavru atma, \% 36.6'sında parazitler(kene, delibaş vs), \% 34.5'inde ishal, \% 31.0'inde ayak hastalıkları, \% 8.4'ünde sarılık ve \% 7.1'inde mastisis hastalığı görüldüğü bilgisi alınmıştır. Iş̧letmelerde en fazla şap (\% 76.1), çiçek (\% 71.8) ve brucella (\% 57.1) aşılarının yapıldı̆̆ 1 ve aşılama programı yapan işletmelerin \% 39.4 olduğu tespit edilmiştir. Karakuş ve Akkol (2013)'un Van ilinde yaptıkları çalışmada küçükbaş hayvan işletmelerinde en fazla parazitler (\% 65.4) ve solunum yolu hastalıklarının (\% 52.2) görüldügüü bildirilmiştir.

Üreticilerin \% 98.6'sı küçükbaş hayvancılık faaliyetleri ile ilgili bilgilere ihtiyaç duyduğunu ve en az bir kaynaktan bilgi aldıklarını ifade etmiştir. Türkiye'de başta Tarım ve Orman Bakanlığına bağlı kurumlar olmak üzere, üniversiteler, sivil toplum kuruluşları, üretici örgütleri, özel tarımsal danışmanlık firmaları ile kamu/özel televizyon kanalları aracılığıyla tarımsal yayım faaliyetleri yürütülmektedir. İncelenen işletmelerde bilgi kaynağı olarak birinci sırada (\% 95.7) İl/İlçe Tarım Müdürlüklerinin geldiği tespit edilmiştir. Türkiye'de tarımsal yayım faaliyetlerinin büyük oranda Tarım İl/İlçe Müdürlükleri tarafından yürütülmesi, üreticilerin eğitim düzeylerinin düşük ve yaş ortalamasının yüksek olması, desteklemeler için kamu kurumlarına başvurma zorunluluğu gibi etkenler söz konusu kurumun ilk bilgi kaynăg 1 olmasına etki etmektedir. Daha sonra sırasıyla diğer üreticiler (\% 80.9), piyasa (\% 73.9), özel veterinerler (\% 71.1), televizyon (\% 64.7), internet (\% 56.3), birlikler (\% 39.4), radyo (\% 15.4), eğitimler (\% 14.1) ve üniversite/araştırma kuruluşları (\% 10.5) gelmektedir (Çizelge 5). Türkiye'de yapılan birçok araştırmada da (Kır, 2010; Karakaya ve Kızıloğlu, 2014) üreticilerin teknik bilgi kaynağı olarak en fazla Tarım İl/ilçe müdürlükleri ve diğer üreticilere müracaat ettikleri tespit edilmiştir. 
Çizelge 5. İşletmelerin bilgi edinme kaynakları (\%)

\begin{tabular}{|c|c|c|c|c|c|}
\hline \multirow[b]{2}{*}{ Bilgi Kaynağı } & \multicolumn{3}{|c|}{ İşletme Büyüklüğü } & \multirow[b]{2}{*}{ Ortalama } & \multirow[b]{2}{*}{$\mathrm{P}$} \\
\hline & $<130$ baş & $130-260$ baş & $>260$ baş & & \\
\hline İl/İlçe Tarım & 93.0 & 95.7 & 98.1 & 95.7 & 0.343 \\
\hline Diğer Üreticiler & 72.1 & 80.8 & 88.4 & 80.9 & 0.005 \\
\hline Pazar ve piyasa & 58.1 & 80.8 & 80.7 & 73.9 & 0.018 \\
\hline Özel veterinerler & 53.5 & 76.6 & 80.8 & 71.1 & 0.037 \\
\hline Televizyon & 46.5 & 68.1 & 76.9 & 64.7 & 0.010 \\
\hline İnternet & 46.5 & 51.0 & 63.4 & 56.3 & 0.418 \\
\hline Birlikler & 18.6 & 36.2 & 59.6 & 39.4 & 0.001 \\
\hline Radyo & 16.3 & 12.8 & 17.3 & 15.4 & 0.811 \\
\hline Eğitimlere katılma & 6.9 & 10.6 & 23.1 & 14.1 & 0.067 \\
\hline Üniversite/Araştırma kur. & 9.3 & 12.8 & 9.6 & 10.5 & 0.834 \\
\hline
\end{tabular}

\section{3. İncelenen işletmelerdeki sorunlar}

İncelenen işletmelerde en çok şikâyet edilen sorunların başında yem fiyatlarının yüksek (\% 99.3) ve desteklemelerin yetersiz/az olması (\% 94.3) gelmektedir. İşletme içi sorunlar olarak çoban bulamama (\% 69.7), süt veriminin düşük olması (\% 57.0), et veriminin düşük olması $(\% 53.5)$ ve küçükbaş hayvancılıkla ilgili bilgi eksikliği (\% 51.4) gelmektedir. Hayvan sağlığı ile ilgili sorunların başında ise aşı/ilaç fiyatlarının yüksek olması (\% 94.4) ve kuzu/oğlak ölümlerinin fazla olması (\%70.4) gelirken kullanılan aşıların etki etmemesi de (\% 33.8) önemli bir sorun olarak tespit edilmiştir. Söz konusu sorunlar dışında meraların yetersiz olması (\% 78.9), birliklerin etkin olmaması (\% 66.2) ve hayvan satışlarında aracıların komisyon ücretleri (\% 65.1) diğer önemli sorunlar olarak tespit edilmiştir.

Üreticiler hayvancılık faaliyetlerinde girdi fiyatlarının yüksek olması, bölgedeki güvenlik sorunları ve gençlerin köyde yaşamak istememesi nedeniyle çoban bulamama gibi sorunlar nedeniyle bölgede hayvancılık faaliyetlerinin giderek azaldığını düşünmektedir.

\section{Sonuç ve Öneriler}

Küçükbaş hayvancılık; dünyanın birçok ülkesinde olduğu gibi Türkiye'nin de ekonomik faaliyetleri içerisinde önemli bir yeri olan kadim faaliyetlerden biridir. Türkiye'nin tüm bölgelerinde yapılan küçükbaş hayvancılık faaliyetleri üreticilere işletmeye düzenli nakit akışı sağlaması, kırsal alanlardan göçü azaltması, bitkisel ürün artıklarının değerlendirilebilmesi gibi fayda sağlarken ülke ekonomisine de nüfusun yeterli ve dengeli beslenmesini sağlama, istihdama katk1, sanayiye girdi temin etme, dış ticarete katkı sağlamaktadır. Elde edilen sonuçlar neticesinde incelenen üreticilerin yaş ortalamalarının yüksek ve eğitim durumlarının düşük olması bölgede hayvancılık faaliyetlerinde yeniliklerin benimsenmesine olumsuz etki edebileceği, ülke genelinde hayvancılık faaliyetlerinin genç bireyler tarafından yapılması için uygulanan teşvik programları ve projelerde gençlere pozitif ayrımcılık yapılması fayda sağlayabilecektir.

Üreticilerin DKKYB üyeliği yüksek olmasına rağmen danışmanlık ve eğitim faaliyetlerinden yeterince faydalanmamaları, birliklerin etkinliği ve aktif çalışmalarını sağlayabilecek bir yapıya dönüşmelerini zorunlu kılmaktadır. Türkiye'nin birçok bölgesinde olduğu gibi Mardin ilinde de çoban bulma konusunda sıkıntı yaşandığı tespit edilmiş olup çobanların sosyal ve ekonomik haklarının garanti altına alındığı ve söz konusu mesleği sürdüren kişilerin sosyal statülerinin yükseltilebileceği eğitim olanaklarının sağlanması (örneğin bölgedeki meslek yüksekokullarında iş garantili sürü yöneticisi bölümlerinin açılması) çobanlık mesleğini özendirici hale getirebilecektir.

\section{Teșekkür}

Bu çalışma Çukurova Üniversitesince desteklenen FDK-2018-10788 no'lu projeden üretilmiştir. 


\section{Kaynakça}

Anonim, (2021). https://tr.wikipedia.org/wiki/Mardin\%27in_il\%C3\%A7eleri. Erişim Tarihi: 18.11.2021.

Ata, N., \& Yılmaz, H. (2015). Türkiye'de Uygulanan Hayvansal Üretimi Destekleme Politikalarının Süt Sığırcıllı̆̆ İşletmelerine Yansımaları: Burdur İli Örneği. Sdü Ziraat Fakültesi Dergisi, 10(1), 44-54.

Bakır, G., \& Mikail, N. (2019). Siirt İlindeki Küçükbaş Hayvancılık İşletmelerinin Yapısal Durumu. Atatürk Üniversitesi Ziraat Fakültesi Dergisi, 50(1), 66-74.

Bilginturan, S., \& Ayhan, V. (2008). Burdur İli Damızlık Koyun Keçi Yetiştiricileri Birliği Üyesi Keçicilik İşletmelerinin Yapısal Özellikleri ve Sorunları Üzerine Bir Araştırma. SDÜ Ziraat Fakültesi Dergisi 9(1), 24-31.

Ceyhan, A., Şekeroğlu, A., Ünalan, A., Çınar, M., Serbester, U., Akyol, E., \& Yılmaz, E. (2015). Niğde İli Koyunculuk İşletmelerinin Yapısal Özellikleri ve Sorunları Üzerine Bir Araştırma. $K S \ddot{U}$ Doğa Bilimleri Dergisi, 18(2), 60-68.

Delgado, C., Rosegrant, M., Steinfeld, H., Ehui, S., \& Courbois, C. (2001). Livestock to 2020:The nextfoodrevolution. Outlook on Agriculture, 30(1), 27-29.

Esin, A., Bakır, M. A., Aydın, C., \& Gürbüzsel, E. (2001). Temel Örnekleme Yöntemleri (Taro Yamane'den Çeviri). Literatür Yayınları, İstanbul.

ESK, (2019). Et ve Süt Kurumu 2019 y1lı Sektör Değerlendirme Raporu. https://www.esk.gov.tr/upload/Node/10255/files/2019 Yili Sektor_Degerlendirme Raporu.p df. Erișim tarihi: 18.06.2020.

FAO, (2014). Sustainable Livestock Production Systems. http://www.fao.org/livestock-systems/en/. Erişim tarihi: 16.09.2020.

FAO, (2019). http://www.fao.org/faostat/en/\#data/QC. Erişim tarihi: 03.12.2020.

Güler, D., \& Saner, G. (2021). Süt Sığırcılı̆̆ı İşletmelerinde Etkinlik Ölçümü: İzmir ve Manisa Örneği. Yüzüncü Yll Üniversitesi Tarım Bilimleri Dergisi, 30(2), 386-397.

Karadaş, K. (2018). Şanlıurfa İlinde Koyunculuk İşletmelerinin Sosyo-Ekonomik Durumu: Siverek İlçesi Örneği. Gümüşhane Üniversitesi Fen Bilimleri Enstitüsü Dergisi, 7(2), 268-279.

Karakaya, E., \& Kızıloğlu, S. (2014). Küçükbaş Hayvancılık İşletmelerinin Örgütlenme Yapısı Bingöl İli Örneği.Türk Tarım ve Doğa Bilimleri Dergisi, 1(4), 552-560.

Karakuş, F., \& Akkol, S. (2013). Van İli Küçükbaş Hayvancılık İşletmelerinin Mevcut Durumu ve Verimliliği Etkileyen Sorunların Tespiti Üzerine Bir Araştırma. Yüzüncü Yıl Üniversitesi Fen Bilimleri Enstitüsü Dergisi, 18(1-2), 9-16.

Karaman, S. (2018). Türkiye Bitkisel ve Hayvansal Üretim Değerlerinin Bölgesel Düzeyde Panel Endeks ile Karşılaştırmalı Analizi. Yüzüncü Yıl Üniversitesi Tarım Bilimleri Dergisi, 28(2), 168-174.

Kır, S. (2010). Konya ili Karapınar ilçesi kü̧̈ükbaş hayvancılık işletmelerinde çalışan kadınların bilgiye ulaşım düzeyleri ve yayım yaklaşımları (Doktora Tezi), Selçuk Üniversitesi Fen Bilimleri Enstitüsü.Konya.

Öğel, H. (2018). Şırnak İlinde Kü̧̧ükbaş Yetiştiriciliğinin Ekonomik Yapısı ve Sorunları (Yüksek Lisans Tezi). Süleyman Demirel Üniversitesi, Fen Bilimleri Enstitüsü. Isparta.

Semerci, A., \& Çelik, A. D. (2016). Türkiye'de Küçükbaş Hayvan Yetiştiriciliğinin Genel Durumu. Mustafa Kemal Üniversitesi Ziraat Fakültesi Dergisi, 21(2),182-196.

Thornton, P. K. (2010). Livestock Production: Recent Trends, Future Prospects. Philosophical Transactions of the Royal Society B: Biological Sciences, 365(1554), 2853-2867.

TÜİK, (2020). Bitkisel ve Hayvansal Üretim Değerleri. http://www.tuik.gov.tr/UstMenu.do?metod=temelist. Erişim tarihi: 04.03.2021. 